\title{
Empirical Analysis of Intonation Activities in EFL Student's Books
}

\author{
Dušan Nikolić*
}

Department of English Language and Literature, University of Niš, Cirila i Metodija 2, 18000 Nišs, Serbia

Corresponding Author: Dušan Nikolić, E-mail: dusannikolic92@yahoo.com

\section{ARTICLE INFO}

Article history

Received: December 07, 2017

Accepted: February 11, 2018

Published: May 01, 2018

Volume: 7 Issue: 3

Advance access: March 2018

Conflicts of interest: None

Funding: None

\begin{abstract}
Intonation instruction has repeatedly proved a challenge for EFL teachers, who avoid getting involved in intonation teaching more than their EFL textbooks demand from them. Since a great number of teachers rely on EFL textbooks when implementing intonation practice, the intonation activities in EFL materials are often central to their classroom. Even though the research on intonation instruction has been well-documented, few papers have explored intonation activities in EFL materials. The present study thus provides an empirical analysis of intonation activities in five EFL student's books series by exploring the overall coverage of intonation activities across the series and the quality of these activities. The results reveal that intonation activities are underrepresented in the EFL student's books, and that discourse intonation deserves more attention in the activities. Considerations for EFL teachers and publishers are also discussed.
\end{abstract}

Key words: Intonation, Discourse, Activities, EFL, Textbooks, Student's Books

\section{INTRODUCTION}

In the main, intonation has been defined as the speech melody or sentence melody, "terms that focus on pitch variations and modulations" (Chun 2002, p. 3). Pitch, length and loudness are linguistic properties of intonation, whereby the change in pitch is responsible for the indication of meaning, and it is thereby the most significant 'ingredient' of intonation. Pitch can be perceived by a listener as high or low, and it is placed on the most prominent syllable of a lexical item. In connected speech or natural discourse, different movements and contours characterize pitch (Toivonen, 2003). While the emphasis is what distinguishes the most prominent elements of an utterance, different pitch movements in tone units affect its grammaticality and linguistic information. In fact, there are general classifications of pitch movement categories related to syntactic structure, where "statements, wh-questions, commands, and exclamations traditionally are described as having falling intonational patterns and yes-no questions as having typically rising patterns" (Chun 2002, p. 52):

1 My back hurts. [statement]<smiles>CCCC</smiles>

2 Are you going to the shops? [yes/no question]

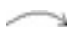

3 Where are you going? [wh-question]

There are numerous theoretical approaches which closely delineate the categories of pitch contours and movements. O'Connor and Arnold (1961) combine rise and fall movements with high and low pitch, developing six intonation pattern categories: low-fall, high-fall, rise-fall, low-rise, high-rise, and fall-rise. While their approach groups tones based on the speakers' attitudes, Halliday and Greaves (2008) remind us of the five phonological intonation pattern categories comprising fall and rise movements, relying on grammatical contrasts. Irrespective of the theoretical notions, in order to predict the potential errors in intonation of L2 speakers, to explicate what kind of intonation patterns there are, and what is their role, general pitch tendency (Chun, 2002) is an aspect of intonation most commonly investigated. In this regard, scholars are quick to claim that intonation overrules grammar in its significance for the L2 acquisition process (Chapman, 2007).

It is well-known that an improper use of intonation provides a fertile ground for miscommunication and negative language attitudes, which confirms how central intonation is to communication. Brazil (1975) concentrates on tone units as basic units of speech which are separated in a stream of speech with short pauses (indicated in writing with//), and each unit contains at least one or two emphatic syllables that have "prominence, a feature which distinguishes them from all other syllables" (Brazil 1997, p. 7). The same author provides an example of prominence:

"//I think on the WHOLE//that THESE ofFICials//do a reMARkably good JOB//" (ibid., p. 7).

\section{Discourse Intonation}

There are no explicit rules as to which items in a tone unit should be stressed, for the prominence is dependent on the 
situational, that is, communicative context (Chun, 2002), where discourse intonation plays a major role. In theorizing about intonation, Brazil (1975), who is among the ranks of pioneers on discourse intonation research, rejects the ideas of intonation (merely) serving grammatical functions and attitudinal notions.

"Rather, what is important for Brazil is the continuous assessment of discourse by the speaker and a choice of one intonation pattern over another for the purpose of achieving coherence and cohesion in the discourse - in other words, the interactional significance of intonation" (Chun 2002, p. 32).

Discourse intonation may thus determine the function of tone units in two ways: given the context of interaction, a speaker might be expressing the already known information, "or the speaker may be introducing something that is not yet shared between the speaker and listener" (Chapman 2007, p. 5). In the former case, rising intonation is most commonly used, while the latter employs falling intonation. The two types of tones are known in the theory as referring and proclaiming tones, often claimed to be essential for differentiating two, on the surface, identical sentences (Brazil 1975). The same utterances regularly occur in different contexts, where intonation does not only bear linguistic information, but it also has "a key role in regulating discourse and is an important indicator of speaker identity, reflecting factors such as physical state, age, gender, psychological state and sociolinguistic membership" (Mennen 2007, p. 1).

\section{Teaching Intonation}

Discourse is seen as the basic unit of communication and it is the focus of more recent studies on pronunciation instruction. This is one of the reasons why "natural discourse is suggested here as the basis for teaching intonation to language learners" (Chun 2002, p. 43). Chun (2002) provides a general outline of the principles that ought to accompany discourse intonation practice, whereby the students should be required to listen to a variety of the materials practicing language use in context (e.g. dialogues, interviews, reporting, storytelling, etc.) rather than isolated sentences. In effect, listening discrimination activities, followed by language production stages, usually prove extremely helpful. The learners must also be familiar with a number of discourse situations which afford them enough opportunities to "encounter meaningful contrasts and to recognize and produce language in a wide range of communicative situations" (ibid., p. 204).

\section{STATEMENT OF THE PROBLEM}

In particular, there are two main directions of the problem. First of all, even though the sizeable literature on discourse intonation has been produced (Dalton \& Seidlhofer, 1994; Celce-Murcia et al., 1996; Chun, 2002), teachers are reluctant when it comes to intonation instruction. Chapman (2007) claims that "incorporating discourse intonation into the EFL classroom remains challenging for teachers and students" (p. 6), which is why most of the teachers chiefly rely on what is given to them in EFL textbooks ${ }^{1}$. Secondly, into- nation is rarely treated systematically in teaching materials (ibid., p. 3), which is why EFL teachers follow the activities from the textbooks used in the curriculum. Rahimpour and Hashemi's (2011) results of the study on the representation of pronunciation in textbooks indicate that pronunciation, and thereby intonation, is generally underrepresented, both in terms of quantity and quality.

\section{THE PURPOSE OF THE STUDY}

Since EFL textbooks are quite important for pronunciation teaching, we endeavour to explore what kind of intonation activities are often used in EFL student's books. Our aim is to offer detailed descriptions of intonation activities used in EFL student's books with a view to determining whether the activities are adequately following the contemporary research findings. In addition, we provide suggestions as to how the teachers may use intonation activities, and how publishers might improve the EFL materials in this respect.

\section{RESEARCH QUESTIONS}

With respect to the objectives of the study, the paper provides answers to the two research questions:

1) What is the overall coverage of intonation activities in EFL student's books?

2) What kind of intonation activities are included in EFL student's books?

\section{METHODOLOGY}

\section{Materials}

In the study, we used five EFL student's books series. Teacher's manuals and workbooks were left out of the research because we considered student's books to be the textbooks most commonly used by the teachers and students. Therefore, it would have been beyond the purview of the paper to have scrutinized teacher's manuals and workbooks, too. Instead, we used twenty EFL books which belonged to the following five series: Project (2, 3, 4, 5), Messages (1, 2, 3, 4), Family and Friends (3, 4, 5, 6), English Plus (1, 2, 3, 4), and Discover English (2, 3, 4, 5). Prior to starting the research, by the means of a short online questionnaire, we had revealed that these five EFL student's books series were most regularly used in middle-schools, in the district of Niš (Serbia). The Project, Family and Friends, and the English Plus series belonged to Oxford University Press (OUP), Pearson Longman published Discover English, while Klett was responsible for Messages. Therefore, we were certain that these EFL student's books series would indeed be an excellent example of typically used EFL materials.

\section{Procedure}

All the activities belonging to pronunciation in every student's book were counted and identified, after which the activities belonging to speaking, listening, reading and writing were counted in order to determine the overall percentage 
of the pronunciation activities. The final list of categories belonging to pronunciation could be found in Table 1 . The categories were largely based on Derwing et al. (2013) classification, whereby the authors distinguished the categories based on the primary focus of the exercise.

Next, we moved on to identify all the intonation activities. Every intonation activity focused either on a) sentence intonation, or b) discourse intonation. As their names foretold, the former group was centred upon practicing intonation patterns within sentences, whereas the latter was focused on discourse. While exploring the activities we also input what types of descriptions followed them. There were three categories of descriptions, overall (Table 2).

Identify included any kind of identification, ordering, putting into tables, etc. Listen and repeat comprised all the listening, repeating, saying types of activities, while explanation was a category which included the activities aiming to raise awareness of intonation patterns in a sentence or discourse. The categories served as the basis for carrying out both quantitative and qualitative analysis of the intonation activities. An example of the entry data was displayed in Appendix 1.

In addition to categories, each activity was described in terms of the function it performed. For example, a sentence intonation activity might have practiced different types of intonation patterns related to grammatical forms, such as statements, wh-questions, yes/no questions, and question tags. Based on the well-grounded theoretical assumptions (Paunović \& Savić, 2008), we believed that discourse intonation ventured beyond grammatical and attitudinal meanings, which was the reason why discourse intonation activities were delineated as well. Such a detailed explanation of intonation activities made the analysis quite comprehensive and holistic.

\section{RESULTS}

\section{Project}

Around 12 per cent of the activities were devoted to pronunciation in the Project series, whereby only around 5 per cent were intonation activities (Table 3 ). All of the activities were dedicated to practicing sentence intonation, for there was no mention or any use of discourse intonation activities. More precisely, the activities focused on intonation of yes/no questions, wh-questions, statements, and question tags. Yes/ no questions and wh-questions, which were the two leading categories, were followed by the predictable falling and rising intonation rule stipulation. Some of the activities were clearly explanatory for the descriptions would encompass the specification of when and how intonation patterns were used. For example, in a description of one of the question tag activities, it was stated that 'intonation normally falls' in the question tags that confirm something. Furthermore, some of the activities were followed by visual design indicating
Table 1. Types of pronunciation activities

\begin{tabular}{l}
\hline Pronunciation activities \\
Sound discrimination \\
Stress \\
Rhythm \\
Intonation \\
Syllables \\
Connected speech \\
Phonetic alphabet \\
Homophones/Homonyms \\
Singing \\
Vocabulary \\
Dialogue reading
\end{tabular}

Table 2. Categories that make types of descriptions

\begin{tabular}{l}
\hline Types of descriptions \\
\hline Identify \\
Listen and repeat \\
Explanation \\
\hline
\end{tabular}

Table 3. The percentage of pronunciation activities in the messages series

\begin{tabular}{lc}
\hline Types of pronunciation activities & Percentage \\
\hline Sound discrimination & 44.2 \\
Stress & 19.6 \\
Vocabulary & 7.6 \\
Intonation & 5.4 \\
The rest & 23.2 \\
\hline
\end{tabular}

whether the sentence intonation either rises or falls, which was regarded extremely useful for the students.

The general pattern could be discerned. Namely, as the students' age and proficiency levels increased, the number of intonation activities decreased. For example, Project 5 had no intonation activities at all. Moreover, certain grammatical structures such as question tags were introduced only in Project 4, when the students were considered to be more mature and ready for structures of greater complexity. The intonation patterns followed this kind of grammatical structures distribution across the entire series.

\section{Messages}

Messages student's books did not pay too much attention to intonation, for there were very few intonation activities across the series ( 8 in total) (Table 4 ). The series relied exclusively on sentence intonation patterns addressing different types of questions and statements. The intonation practiced in statements was often used to consolidate the previously learnt phrases, such as I've got a headache. Every instance of intonation activities which practiced questions referred to the difference between falling and rising patterns in wh- and 
yes/no questions, respectively. Messages 4, which had merely one intonation activity, dedicated this activity to practicing emotional reactions in simple short answers such as No, you don't! or Yes, I do. In some of the activities, images helped explaining when the students should have used falling or rising intonation. Unlike in the Project series, there were no explicit (written) rules stating how to use the given intonation pattern.

The same arrangement - the decrease in intonation activities alongside the increase of students' age and proficiency levels - was noticed in the Messages series as well. Yet, while the Project series practiced intonation in question tags and in certain statements expressing attitudes and emotions, the Messages student's books lacked these kinds of activities. Furthermore, both the Project and Messages series displayed a tendency to practice intonation patterns alongside grammatical structures.

\section{Family and Friends}

The Family and Friends series did not have any intonation activities. They focused primarily on pronunciation of lexical items and sound discrimination. Hence, this series was centred upon exposing students to segmental rather than suprasegmental features, which was most certainly not beneficial for EFL students.

\section{English Plus}

English Plus devoted around 25 per cent of their pronunciation activities to intonation (Table 5), whereby around 60 per cent were sentence intonation activities, while 40 per cent belonged to discourse intonation. English Plus was the only series which had activities practicing discourse intonation, which was employed only through the written dialogue. Dialogues carried a variety of contextual information that produced a range of possibilities for speakers. With respect to sentence intonation, intonation in yes/no questions,

Table 4. The percentage of pronunciation activities in the Messages series

\begin{tabular}{lc}
\hline Types of pronunciation activities & Percentage \\
\hline Sound discrimination & 48.5 \\
Stress & 13.6 \\
Vocabulary & 14.6 \\
Intonation & 7.8 \\
The rest & 15.5 \\
\hline
\end{tabular}

Table 5. The percentage of pronunciation activities in the English Plus series

\begin{tabular}{lc}
\hline Pronunciation activities & Percentage \\
\hline Dialogue reading & 43.6 \\
Intonation & 25.6 \\
Vocabulary & 17.9 \\
Stress & 11.5 \\
\hline
\end{tabular}

wh-questions, question tags, and in statements was practiced, which was consistent with the results found in the rest of the textbooks. The majority of the activities demanded listening and repeating, while there were a few identification activities, and only one explanatory activity which asked from the learners to deduce how to express surprise by using sentence intonation. Hence, in terms of quantity, there were very few intonation activities in this series, but the activities carefully distributed sentence intonation and discourse intonation patterns across the series, providing a number of different uses.

\section{Discover English}

The Discover English series devoted 10 per cent of their activities to pronunciation, whereby intonation activities assumed acceptable 22 per cent. Unlike in other student's books series, the number of activities did not drastically decrease as the students' age and proficiency levels increased. All the intonation activities were centred upon practicing sentence intonation patterns. The activities were chiefly focused on statements which expressed a range of emotions (surprise, sadness, anger, etc.), while there were some instances of intonation practice through yes/no and wh-questions. This series did not devote any attention to question tag intonation patterns. In addition, almost all the intonation activities were listen and repeat activities. The visual design of the activities was maintained throughout the entire series, but it was of minimal help to the students since it did not show pitch movements in any way.

\section{Overall}

With respect to the number of the activities devoted to intonation, it could be said the overall coverage was below the appropriate standard (Figure 1). Family and Friends student's books did not have a single intonation activity, while the Messages and Project series had around 6 per cent of their pronunciation activities intended for intonation practice. The number of intonation activities in Discover English and English Plus was at an appropriate level (around 23 per cent).

Most of the intonation activities across all the series concentrated on sentence intonation tasks (Figure 2), which encompassed the intonation of yes/no questions, wh-questions, statements, and question tags. In every textbook, there was either a linguistic or visual explanation as to how to distinguish between yes/no and wh-questions intonation patterns.

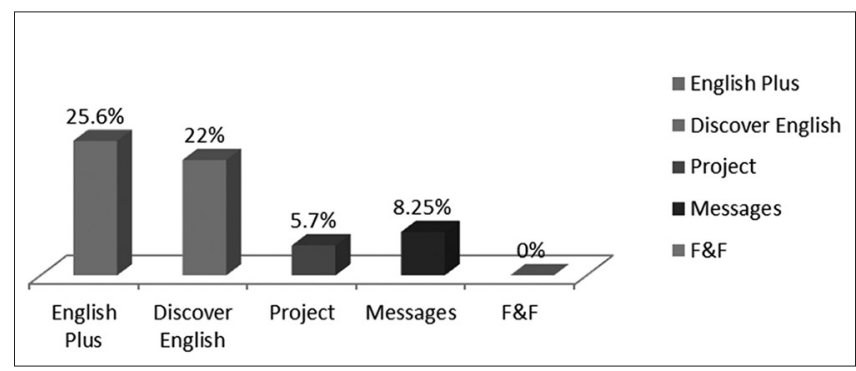

Figure 1. The percentage of intonation activities across the series (compared with other pronunciation activities) 


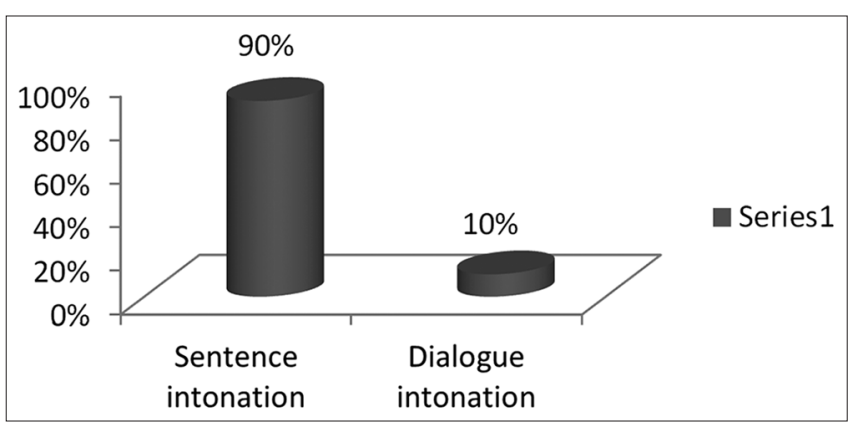

Figure 2. Overall percentage of sentence and discourse intonation activities in all the series

The majority of the intonation activities that practiced question tags explained when and how intonation ought to be used to express either confirmation or curiosity. As regards discourse intonation, English Plus made a considerable balance in this respect, for the series used around 40 per cent of discourse intonation activities which focused exclusively on short pre-written dialogues.

With respect to the types of descriptions, quite predictably, most of the activities focused on listening and repeating (76 per cent), where the students were required to listen to the intonation patterns and then copy them. Around 14 per cent of the intonation activities were devoted to identification and explanation categories each.

\section{DISCUSSION}

Based on the findings, it could be said that most of the EFL student's books do not devote enough attention to intonation practice, which could imply that the authors of the textbooks are careful not to overwhelm the teachers and students with intonation practice. One of the reasons for this might be the fact that the publishers are generally aware of the teachers' reluctant attitude towards implementing intonation practice in their classrooms. Additionally, such a low number of intonation activities also indicate the authors' and scholars' disengagement with intonation practice. While numerous activities focus on the proper pronunciation of lexical items and sound discrimination, suprasegmental features are, to a large extent, disregarded, which suggests the publishers' unfamiliarity with or deliberate neglect of the contemporary research findings.

The findings of the study have also revealed that the quality of the intonation activities across the EFL student's books series is generally inadequate, i.e. substandard. Most of the EFL student's books put their emphasis on sentence intonation and listen and repeat types of descriptions. Firstly, even though most of the EFL student's books practice different sentence intonation patterns, where the students are exposed to a variety of intonation possibilities, these opportunities are chiefly limited to an individual sentence practice. Instead of using discourse intonation activities as proposed by some scholars (Chun, 2002; Chapman, 2007), EFL textbooks rely on sentence intonation. Therefore, albeit the activities include a variety of grammatical and attitudinal functions, they are restricted to a single utterance, whereby the em- phasis and guidance is not towards natural communicative situations. Secondly, listen and repeat activities restrict EFL learners to mechanical reproduction of what has been heard, wherein the students are denied the authentic communicative situations. Moreover, both the process of listening and producing intonation patterns ought to move beyond the traditional drill-like techniques. One of the methods to do this is to employ discourse intonation practice.

The identified intonation patterns neglect the possibility of using sentences in communication and for communicative purposes, whereby the most optimal way to practice intonation would be through discourse. Discourse intonation activities appear only in one of the series, practicing intonation through dialogues. In such cases, EFL students are exposed to turn taking, suggestion making, and expressing a range of psychological and emotional states (anger, surprise, amazement, etc.), which is considered to be invaluable for natural interaction (ibid.). The English Plus series thus acknowledges the role of discourse intonation and devotes some attention to it in its activities. Still, it is undeniable that the English Plus has very few pronunciation activities overall, and that there are no discourse intonation activities in the rest of the analysed textbooks.

\section{Considerations for Teachers and Publishers}

The teachers should have their freedom upon incorporating skills in the classroom and carrying out the activities. Still, it needs to be repeated that most of the teachers rely on the textbook activities (Kilickaya, 2004), which is why they require training into how to conduct these activities. Additionally, since "the very traditional textbooks tended to set up one-sided production or a stimulus-response structure, not true social interactions" (Chun 2002, p. 142), Chun (ibid., p. 203) offers a list of auditory discrimination practice that can be useful, especially with regard to discourse intonation. Although there are very few discourse intonation activities in the EFL student's books, even the activities practicing sentence intonation could be expanded to the extent of discourse in order to yield interaction as spontaneous as possible. For example, based on the given sentences in EFL textbooks, the students might be required to tell a story or report on an incident. In addition, the students may work in groups discussing a particular topic, whereby discourse intonation practice becomes fairly natural. Therefore, the principle behind the classroom intonation practice is the consideration of intonation acquisition as a highly-conscious process in as authentic situations.

In this respect, the findings of this study, which has revealed a decrease in the number of intonation activities as the students get older and more proficient, indicate serious issues and contradictions. It is well-known that beyond the age of eleven or twelve children are unable to attain native-like L2 pronunciation, and thereby intonation; none the less, this does not automatically imply that more mature and older students should be deprived of the same amount of intonation practice. In fact, these L2 learners should practice it even more, for they are the ones in need of greater exposure and L2 production. EFL students who are cognitively more ma- 
ture are actually quite ready to receive explicit instructions concerning intonation pattern discrimination and intonation use as a part of the awareness-raising training. Bearing all this evidence in mind, the publishers should consider 1) providing more discourse intonation activities in EFL student's books, and 2) including more explanatory activities. Lastly, the intonation activities in EFL student's books should work towards clearly outlined goals of providing the EFL learners with "the opportunity to demonstrate sociolinguistic, discourse, or strategic competence" (ibid., p. 83).

\section{CONCLUSION}

In the study, with the aim of answering the most important research questions, we investigated how EFL student's books addressed intonation through their activities, whereby it was revealed that overall coverage of the intonation activities in the EFL student's books was below the acceptable standard. There were very few intonation activities compared with the activities practicing, for example, sound discrimination. The number of intonation activities was reduced across the series, which was well against the research on intonation acquisition and instruction. Additionally, one of the textbook series did not dedicate any activity to intonation at all.

In terms of the second research question, i.e. regarding the types of intonation activities, most of them were focused on sentence intonation followed by listening and repeating types of descriptions, which indicated the lack of awareness to implement discourse intonation activities and more communicative types of tasks. Most of the activities practiced grammatical functions of the sentences, such as wh-questions and yes/no questions, and attitudinal and emotional states, disregarding the above-sentential function of intonation patterns. After discussing all these findings, the study put forward certain suggestions as to how EFL teachers might use intonation activities, and what the publishers should consider modifying in the future.

\section{END NOTE}

1. The term 'textbook' will exclusively denote a book used by teachers and students in EFL classrooms.

\section{REFERENCES}

Brazil, D. C. (1975). Discourse intonation (Discourse Analysis Monographs 1). Birmingham: University of Birmingham. English Language Research.

Brazil, D. (1997). The Communicative Value of Intonation in English. Cambridge: Cambridge University Press.

Celce-Murcia, M., Brinton, D. M., \& Goodwin, J. M. (1996). Teaching pronunciation: A reference for teachers of English to speakers of other languages. Cambridge University Press.

Chapman, M. (2007). Theory and practice of teaching discourse intonation. ELT journal, 61(1), 3-11. DOI: https://doi.org/10.1093/elt/ccl039.
Chun, D. M. (2002). Discourse intonation in L2: From theory and research to practice (Vol. 1). John Benjamins Publishing. DOI: 10.1075/1llt.1.

Dalton, C., \& Seidlhofer, B. (1994). Pronunciation. Oxford: Oxford University Press.

Derwing, T. M., Diepenbroek, L. G., \& Foote, J. A. (2013). How well do general-skills ESL textbooks address pronunciation? TESL Canada Journal, 30(1), 22-44.

Halliday, M. A. K., \& Greaves, W. S. (2008). Intonation in the Grammar of English. Equinox Pub.

Mennen, I. (2007). Phonological and phonetic influences in non-native intonation. Trends in linguistics studies and monographs. Available at http://eresearch.qmu. ac.uk/151/(Unpublished).

Kilickaya, F., (2004). Authentic materials and cultural content in EFL classrooms. The Internet TESL Journal, 10(7), 1-6. Available at http://iteslj.org/Techniques/ Kilickaya-AutenticMaterial.html.

O’Conner, J. D., \& Arnold, G. F. (1961). Intonation of Colloquial English: A Practical Handbook. Longmans.

Paunović, T., \& Savić, M. (2008). Discourse intonation-Making it work. In S. Komar \& U. Mozetić, (Eds.) As you write it: issues in literature, language, and translation in the context of Europe in the 21 $1^{\text {st }}$ century. 5(1-2), 5775. Slovene Association for the Study of English. DOI: http://dx.doi.org/10.4312/elope.5.1-2.57-75.

Rahimpour, M., \& Hashemi, R. (2011). Textbook selection and evaluation in EFL context. World Journal of Education, 1(2), 62-68. DOI: https://doi.org/10.5430/wje. v1n2p62.

Toivanen, J. (2003). Tone choice in the English intonation of proficient non-native speakers. In Proceedings of Fonetik (pp. 165-168).

Student's Books Surveyed

Hutchinson, T. (2008). Project (2,3,4,5) Third Edition: Student's Book. Oxford: Oxford University Press.

Goodey, D. and Goodey, N. (2005). Messages $(1,2,3,4)$ Student's Book. Belgrade: Klett.

Thompson, T. and Simmons, N. (2009). Family and Friends: 3: Class Book and MultiROM Pack. Oxford: Oxford University Press.

Simmons, N. (2010). Family and Friends: 4: Class Book and MultiROM Pack. Oxford: Oxford University Press.

Thompson, T. (2010). Family and Friends: 5: Class Book and MultiROM Pack. Oxford: Oxford University Press.

Quintana, J. (2010). Family and Friends: 6: Class Book and MultiROM Pack. Oxford: Oxford University Press.

Wetz, B., \& Pye, D. (2010). English Plus (1,3,4): Student's Book. Oxford: Oxford University Press.

Wetz, B., Styring, J., and Tims, N. (2010). English Plus 2: Student's Book. Oxford: Oxford University Press.

Wildman, J. and Hearn, I. (2010). Discover English (2,3): Student's Book. Essex: Pearson Longman.

Kilbey, L. (2010). Discover English (4,5): Student's Book. Essex: Pearson Longman. 


\section{APPENDIX}

Appendix A. Entry data of intonation activities in English Plus 4

\begin{tabular}{llll}
\hline $\begin{array}{l}\text { Page } \\
\text { No. }\end{array}$ & Unit & Focus & Description \\
\hline 14 & 1 & Discourse intonation & Listen and repeat \\
24 & 2 & Sentence intonation & Listen and repeat \\
24 & 2 & Sentence intonation & Identify \\
34 & 3 & Sentence intonation & Identify \\
34 & 3 & Sentence intonation & Listen and repeat \\
43 & 4 & Sentence intonation & Listen and repeat \\
44 & 4 & Sentence intonation & Listen and repeat \\
54 & 5 & Discourse intonation & Identify \\
64 & 6 & Sentence intonation & Listen and repeat \\
64 & 6 & Sentence intonation & Listen and repeat \\
74 & 7 & Discourse intonation & Listen and repeat \\
\hline 4 & 8 & Discourse intonation & Listen and repeat \\
\hline
\end{tabular}

